\title{
ANALYZING THE USES OF DIFFERENT VIRAL MARKETING TECHNIQUES OF BANK: A STUDY ON A COMMERCIAL BANK
}

\author{
Dipu Roy \\ Bachelor of Business Administration \\ Department of Marketing \\ Faculty of Business Studies \\ Bangabandhu Sheikh Mujibur Rahman Science and Technology University \\ Gopalganj-8100, Bangladesh \\ E-mail: dipuroymkt@gmail.com \\ Sharmin Nahar Eti \\ Master of Business Administration \\ Department of Marketing \\ Faculty of Business Studies \\ Bangabandhu Sheikh Mujibur Rahman Science and Technology University \\ Gopalganj-8100, Bangladesh \\ E-mail: sharminbsmrstu180@gmail.com \\ Sabeha Jannat \\ Bachelor of Business Administration \\ Department of Marketing \\ Eden Mohila College Affiliated with University of Dhaka \\ Dhaka-1205, Bangladesh \\ E-mail: sabehajannat@gmail.com
}

Received: November 21, 2021 Accepted: December 20, $2021 \quad$ Online Published: January 24, 2022

DOI: 10.46281/ijmri.v6i1.1565

URL: https://doi.org/10.46281/ijmri.v6i1.1565

\begin{abstract}
The paper focuses on analyzing the uses of viral marketing techniques in the banking industry. In this paper, the bank will learn to use the viral marketing techniques. This report aims to analyze the uses of viral marketing techniques in Khulna city. The paper's significant findings are different use of viral marketing techniques as marketing strategy in the banking industry. Viral marketing techniques are more effective than any other marketing strategy to reach potential customers. To attract customer attention the use of viral marketing is effective. Spreading information is the best use of viral marketing techniques to measure customer satisfaction. To make customers happy, creating a positive attitude of customer's mind viral marketing plays a significant role. The researcher's findings also suggest that viral marketing techniques are more effective than any other marketing strategy. To make information available Facebook, webpage and website has no
\end{abstract}


alternative sources. So banks should be used viral marketing techniques. To get trustworthiness and make customers happier, viral marketing is the best use as a marketing strategy. Creating a positive attitude on customer mind and establishing a new brand viral marketing would be effective, so it should be maintained. According to factors analysis, if bank use 7 factors and maintain those factors properly, it will bring success.

Keywords: Bank, Social Media, Viral Marketing.

JEL Classification Codes: M38.

\section{INTRODUCTION}

Communication and positioning with customers are important for the banking sector .Viral marketing exploits existing social media and networks by encouraging customers to share product information with their friends (Abdullah, Ward \& Ahmed, 2016). In this era of technology \& viral marketing, people are more addicted to new technology. People are passing their day by using social media, like Facebook, twitter, youtube, the internet etc. We know that marketing has given enough change over the recent years and it has been played importance role by using viral marketing. Viral marketing is a marketing phenomenon that encourages people to pass along a marketing message voluntarily (Anderson, 2008). Viral marketing refer that viral marketing or viral advertising is a business technique that uses existing social networks to develop a product mainly on different social media platforms. In the banking sector the most popular use of different viral marketing techniques. They attract the customers and send the right message for right person community (Akhter et al., 2020a; Akhter et al., 2020b; Jahan et al., 2020). Viral marketing is the new strategy and a successful stage because of available access instruments (laptop, smartphone, tab) etc. If a bank wants to reach peck, it must cope with the growing field. People are using technology because it reduces cost, saves time $\&$ available at any time. For all these reasons, the bank can select it as its one of the marketing factors. Viral marketing spreads through social networks and it is a very cheap mode of marketing. As a result a commercial bank do not need to spent massive amounts of money on traditional expensive marketing programs (Asheq et al., 2021; Kumar et al., 2019; Al Amin et al., 2020; Akhter et al., 2021).

Viral marketing is the virtual word of mouth. As a result a high rate of pass along from a user to another user. The viral marketing technique is more valuable for both consumer and bank .consumer get things they wanted and bank provide information what they wanted. The viral marketing is specifically related to its use of existing digital network by which people search the information about bank through Website, YouTube, twitter. After getting service, satisfaction builds trust on the customer mind which is help to viral marketing techniques. Multiple social media formats are used in the process, which includes social networks sites such as you tube, email communication, Facebook, webpage and many other forms of electronic media. This marketing technique on social networks and by words of mouth generates publicity to increase brand awareness. The objective of using this technique is an increase in product sales through a carefully designed viral process.

The fundamental of marketing is to target the right customers with the right valuable message in order to meet their needs and wants profitability. At present viral marketing is a new strategy used in the promotion of goods and brands. Viral marketing is successful campaign can work miracles for banking sector. Viral marketing can be defined as the disposal of information about a brand or product in a short period of time among the mass media, which has helped to work very well for thousands of marketers and helped them improve the growth of their banking 
sectors. Viral marketing raises interest in a brand or product (and therefore potential sales) through messages that extend quickly from person to person. Viral marketing is the best way to reduce advertising costs and it is not expensive to launch but it is very effective and fast in receipt the message over the target customer. Viral marketing can reach many of people, now there is a new generation of marketing methods that has been taken. We are living in the age of the internet. Viral marketing is one of very few methods that can create explosive growth in every little time and once it hits people to speeds very fast everywhere that positively affects the banking sectors. Viral marketing helps in creating the best view for bank. If developing the banking sector and enhancing brand viral marketing is one of the most critical strategies to attract customers and raise brand awareness. Though viral marketing the brand can take benefit of the internet, especially social media, is massive count for just about anything and everything. When people find jealous, humorous, interest or shocking, they are darling to this with people from their social network. So the focus of this study is the viral marketing technique that is used as marketing strategy. As Bangladesh economy is growing day by day (Tu et al., 2021; Ara et al., 2015; Ali et al., 2021; Ali et al., 2020; Baqir et al., 2020; Batool et al., 2021; Islam \& Bhuiyan 2021; Islam \& Barghouthi, 2017; Islam \& Miajee, 2018; Islam, 2016a; Islam, 2016b; Islam, 2016c; Islam et al., 2015; Hossain et al., 2017; Islam, 2015; Islam \& Barghouthi, 2017; Islam et al., 2021; Sharif \& Karim, 2017; Karim et al., 2021), it is essential to study this viral marketing.

\section{LITERATURE REVIEW}

According to Bhattacharya, Gaurav \& Ghosh (2019), viral marketing is advertising in a way that it raised products and services in a direct method. Viral marketing award the benefits of contact and interaction of individuals and brands at network platforms by aurally. According to Yang (2013), viral marketing can prove to be very effective in the following situation. Firstly, viral marketing works well for new types of products and services that are novelty in some ways, especially the innovative feature of the new product. Or service can serve as a Powerful marketing message with the potential of going viral, secondly, the potential benefits of viral marketing are further increased when the benefits associated with the use of products or services are real and thirdly, viral marketing can also prove to be highly effective in situation when products and services being promoted cater for the needs of specific group of people. In the other words, members of such groups can facilitate the spread of marketing message within the group. Viral marketing communication refers to any positive or negative statement made by potential, actual and former customer about a product or a company via the internet. Viral marketing in its summary is marketing messages legislate for spread from one person to the next. This is done by inspiring or rewarding people who agree by sharing it with their companion (Tsekouropoulos, 2019). Viral marketing is any marketing strategy that covers websites or users to pass on a marketing message to other sites or users, creating a potentially expositive growth in the message as view and effect. Viral marketing is the act of having a message expansion promptly through various social media networks. The aim of viral marketing is to rising brand awareness fast.

Consumer's attitude is related to consumer behavior or the various and changing perspective of consumers on the products and services that they need, want and acquire. In this generation, consumers are changing and are becoming more "dystopian and alienating seeking compensation through the competition sings and the superficial" (Lindgreen, Dobele \& Vanhamme, 2013). The viral marketing concept turns customers to pass along messages to other people. It is essential that bank and customers to understand the information about products, services, and brand .And know the customers mind. If a message gets a positive effect through a 
viral marketing this can be spread very fast and maybe lead to a purchase in the bank products and services.

On the other hand, a negative world spread just as fast but instead may shock the customers further away from buy bank products and services (Roy et al., 2014). The largest drawback of viral marketing methods is the lack of control that comes as a byproduct with nearly every instance of this advertisement. Once it expands to enough people, the advert maker no longer possesses rule over its distribution and use. This means that any mistakes or error in the ad that people may find and take offence to will be exceedingly difficult to correct (Miller \& Lammas, 2010).

\section{METHODOLOGY}

The purpose of the research indicates that the researcher project paper is both exploratory and descriptive research. This is exploratory when the data was collected through in-depth interviews and it is descriptive when the data is analyzed through a structured questionnaire. The primary purpose of this report is to explore the uses of viral marketing concepts of a commercial bank. This study had both qualitative and quantitative approaches. It was found most suitable to the researcher purpose. For the study's first objective, the researcher used observational research as a qualitative analysis tool to identify different viral marketing techniques of a commercial bank. For the study's second objective, the researcher used quantitative analysis where the statistical package of social science version 16 was used to analyze the uses of different viral marketing techniques of a commercial bank. Lastly, the researcher recommends some guidelines for a commercial bank. Both secondary and primary data were necessary for the fulfillment of the research project. Secondary data was collected from various published documents in rated books, journals, newspapers, magazines and websites. For getting primary data respective respondents were interviewed personality to collect the data required through a structured questionnaire. Nonprobability convenience sampling technique has been used for the sampling purpose. In this study the researcher distributed this questionnaire to the marketing expert and employees of a commercial bank. The sample size is 100 and the target respondents are the marketing experts and employees of a commercial bank. The researcher used liker scaling techniques as sampling scaling where $1=$ strongly agree, $2=$ agree, $3=$ neutral, $4=$ disagree, $5=$ strategy disagree and open-ended question. For the analysis of the data that are found through questionnaires, the researcher applied frequency analysis.

\section{RESULTS \& DISCUSSION}

Table 1. Frequency of table show age of the respondents

\begin{tabular}{|c|c|c|}
\hline Age & Frequency & Percent \\
\hline $25-35$ & 20 & 20 \\
\hline $35-45$ & 44 & 44 \\
\hline $45-55$ & 18 & 18 \\
\hline $55-65$ & 18 & 18 \\
\hline Total & 100 & 100 \\
\hline
\end{tabular}

This table above shows that $20 \%(n=20)$ of the respondents $25-35$ age, $44 \%(n=44)$ of the respondents $35-45$ age, $18 \%(n=18)$ of the respondents $45-55$ age, $18 \%(n=18)$ of the respondents 55-65 age. 
Table 2. Frequency of table show gender status of the respondents.

\begin{tabular}{|c|c|c|}
\hline Name & Frequency & Percent \\
\hline Female & 15 & 15 \\
\hline Male & 85 & 85 \\
\hline Total & 100 & 100 \\
\hline
\end{tabular}

The study targeted 100 respondents. Among them they are $15 \%(n=15)$ of the respondents are female and $85 \%(n=85)$ of the respondents are male. This table shows that maximum respondents are male.

Table 3. Frequency of table show executive and employee use viral marketing techniques in a very effective way

\begin{tabular}{|c|c|c|}
\hline & Frequency & Percent \\
\hline "Strongly agree" & 64 & 64 \\
\hline "Agree" & 31 & 31 \\
\hline "Disagree" & 5 & 5 \\
\hline Total & 100 & 100 \\
\hline
\end{tabular}

This table above show that $64 \%(n=64)$ of the respondents strongly agree and $31 \%(n=31)$ of the respondents agree that using viral marketing techniques are used in a very effective way than any other marketing strategy because it can grasp customer attention than any other marketing strategy. By the information of this table, this is the evidence that using viral marketing techniques are effective.

Table 4. Frequency of table show executives and employee are using viral marketing strategies for creating new customers.

\begin{tabular}{|c|c|c|}
\hline & Frequency & Percent \\
\hline "Strongly agree" & 19 & 19 \\
\hline "Agree" & 50 & 50 \\
\hline "Neutral" & 6 & 6 \\
\hline "Disagree" & 20 & 20 \\
\hline "Strongly disagree" & 5 & 5 \\
\hline Total & 100 & 100 \\
\hline
\end{tabular}

This table above shows that $19 \%(\mathrm{n}=19)$ of the respondents strongly agree and $50 \%(\mathrm{n}=50)$ of the respondents agree that using viral marketing techniques are creating new customers because it can grasp customer attention of new customers. By the information of this table, it is the evidence that viral marketing techniques are creating new customers. 
Table 5. Frequency of table show executives and employee are using viral marketing techniques and by it bank can reach their potential customers.

\begin{tabular}{|c|c|c|}
\hline & Frequency & Percent \\
\hline "Strongly agree" & 16 & 16 \\
\hline "Agree" & 64 & 64 \\
\hline "Neutral" & 6 & 6 \\
\hline "Disagree" & 10 & 10 \\
\hline "Strongly disagree" & 4 & 4 \\
\hline Total & 100 & 100 \\
\hline
\end{tabular}

This table above shows that $16 \%(n=16)$ of the respondents strongly agree and $64 \%(n=64)$ of the respondents agree that they uses viral marketing techniques to reach their potential customer because it is increasing customer's interest. By the information of this table, it is the evidence that viral marketing techniques creating new customer.

Table 6. Frequency of table show executives and employee admit that uses of viral marketing techniques are profitable

\begin{tabular}{|c|c|c|}
\hline & Frequency & Percent \\
\hline "Strongly agree" & 23 & 23 \\
\hline "Agree" & 71 & 71 \\
\hline "Disagree" & 6 & 6 \\
\hline Total & 100 & 100 \\
\hline
\end{tabular}

This table above show that $71 \%(n=71)$ of the respondents agree and $23 \%(n=23)$ of the respondents strongly agree that using viral marketing techniques are profitable for a commercial bank because it reduces cost and easily grasp customers attention. By the information of this table, it is the evidence that viral marketing techniques are profitable for a commercial bank.

Table 7. Frequency of table show executive and employee using facebook marketing is very effective source of communication to attract the customers.

\begin{tabular}{|c|c|c|}
\hline & Frequency & Percent \\
\hline "Strongly agree" & 18 & 18 \\
\hline "Agree" & 57 & 57 \\
\hline "Neutral" & 10 & 10 \\
\hline "Disagree" & 9 & 9 \\
\hline "Strongly disagree" & 6 & 6 \\
\hline Total & 100 & 100 \\
\hline
\end{tabular}

This table above shows that $57 \%(n=57)$ of the respondents agree and $18 \%(n=18)$ of the respondents strongly agree that using Facebook marketing is very effective source of communication to attract the customers because it can pass speedy information. By the information of this table, it is the evidence that Facebook marketing is very effective source of communication. 
Table 8. Frequency of table show executive and employee using facebook marketing techniques is cheaper sources than any other sources to attract the customers.

\begin{tabular}{|c|c|c|}
\hline & Frequency & Percent \\
\hline "Strongly agree" & 13 & 13 \\
\hline "Agree" & 64 & 64 \\
\hline "Neutral" & 6 & 6 \\
\hline "Disagree" & 10 & 10 \\
\hline "Strongly disagree" & 7 & 7 \\
\hline Total & 100 & 100 \\
\hline
\end{tabular}

This table above shows that $13 \%(n=13)$ of the respondents strongly agree and $64 \%(n=$ 64 ) of the respondents agree that using Facebook marketing techniques is cheaper sources than any other sources to attract the customers of a commercial bank because it is easily attract customer and it is the biggest opportunity for a commercial bank. Facebook marketing is cheaper sources than any other sources. By the information of this table, it is the evidence that Facebook marketing technique is cheaper source than any other sources to attract the customers of a commercial bank.

Table 9. Frequency Of Table Show Executives And Employees Admit Using Facebook Is Very Popular Marketing Techniques For Promoting a commercial bank.

\begin{tabular}{|c|c|c|}
\hline & Frequency & Percent \\
\hline "Strongly agree" & 16 & 16 \\
\hline "Agree" & 55 & 55 \\
\hline "Neutral" & 9 & 9 \\
\hline "Disagree" & 10 & 10 \\
\hline "Strongly disagree" & 10 & 10 \\
\hline Total & 100 & 100 \\
\hline
\end{tabular}

This table above shows that $16 \%(n=16)$ of the respondents strongly agree and $55 \%$ $(n=55)$ of the respondents agree that using Facebook is very popular marketing techniques for promoting a commercial bank because Facebook is a very popular marketing technique than other marketing strategies. By the information of this table, it is the evidence that Facebook is very popular marketing technique for promoting a commercial bank.

After the face to face interview with the customer in Khulna city, the reporter got the following information from them.

Maximum customers did not know about viral marketing techniques. There are few people who know about viral marketing. Only the college or university students and some of the people who use social media were known the viral marketing. When we describe viral marketing techniques they realize it clearly. It can be said that very few people know about the viral marketing.

Maximum people do not visit a commercial bank website. People know information talking with the executive. When we told them that all bank information includes a commercial bank website, they understood it and were interested in searching for information. But some university students visit a commercial bank website. Very few job holder and business man visited a commercial bank website. People know information visit the commercial bank website. Maximum 
people use Facebook. People saw different kind of viral video about bank. The $60 \%$ student know a commercial bank uses Facebook marketing 20\% job holder and $20 \%$ of business man know a commercial bank uses Facebook marketing. People do not know what viral marketing is. When we discussed viral marketing, people said that they face it but they do not know it. After we finished my lecture people easily understood it and said that it is convenient for them. They always get information from Facebook, website and webpage. Yes, customers believe that they get more reliable information from website of a commercial bank. Maximum customer response yes, they visit a commercial bank website. People get information which is need for them. People search information and find more reliable information through a commercial bank website. Most of the customers said that Facebook marketing is easier for customers. Generally, 80\% students use Facebook. People can easily get information from Facebook. Facebook marketing is easier for customers. Maximum people heard about a commercial bank through Facebook media. The bank uses Facebook and this page provide all information for customer attraction and aware of the knowledge about a commercial bank goods and services. Communication is very important, especially in banking sectors, so a commercial bank spreads information through Facebook, web page, and website.

Now a day viral marketing becomes an effective marketing strategy to reach customers. Viral marketing plays a more important role. The report tried to identify and analyze the uses of viral marketing strategy in a commercial bank in Khulna city, and also tried to recommend some guidelines for executive who uses viral marketing strategy in a commercial bank services. Based on the findings of the report, most of the identified use of the viral marketing customers are aware of the brand and create positive impact, which are useful to reach customer, which is marketing strategy. Viral marketing techniques are Facebook, website, web page, tube, E-mail create customer awareness. According to the finding, the uses of viral marketing as marketing strategy in Khulna city are being used as viral marketing techniques in a very effective way. Customers can easily get information through website and their satisfaction level is high because customers easily access their website. The second most popular use of viral marketing techniques in a commercial bank is creating new customers. The use of webpage marketing is the expression of customer satisfaction, which is an effective strategy for creating a new one. According to findings, using viral marketing techniques is more effective for potential customers and existing customers. The third significant use of viral marketing techniques is profitable for banks because it can easily grasp customer attention and play a non-paid advertisement. Customer can easily see the advertising through the commercial bank Facebook page. It attracts potential customers. According to the finding, non-paid advertisement shows the satisfaction level of satisfied customers. The fourth uses of viral marketing techniques are to reach potential customers. Viral marketing is the big opportunity for bank the use of this marketing strategy presents the happiness, satisfaction level that attracts potential customers easily. According to the findings to catch up with potential customers, viral marketing techniques are effective and useful. The five most use of viral marketing techniques is sharing to spread information through Facebook marketing. Facebook marketing has an important role in making information available and increasing awareness about bank service that insists customers get service. According to findings, spreading information is most effective for marketing strategy. The six uses of viral marketing techniques are to hold the existing customer and inspire potential customer. Bank needs to increase trustworthiness make the customer reliable on bank. According to the findings, trustworthiness helps to build existing customer. The seven most use of viral marketing techniques as marketing strategy is to provide better service to bank clients. Facebook marketing introduce about bank product and service as a 
result customer are aware of the brand and create new brand image. The eight most use of viral marketing techniques as marketing strategy is to draw a customer attention that is much effective than any other strategy. Customers are more reliable when they informed about satisfied customer experience. According to the finding, using viral marketing techniques for drawing customer attention is effective strategy. The nine most use of viral marketing techniques is to suggest better service. Viral marketing techniques suggest that employees give better service or different techniques to give their best that helps to get customers. The ten most use of viral marketing techniques is to make client happier. Viral marketing techniques can make satisfy customer providing information through website about bank. It make client happier. The eleventh most use of viral marketing techniques is to create positive attitude in customer mind. It makes customer or client positive toward bank because positive attitude present positive expression. According to the finding, creating positive attitude in customer mind is the best use of marketing strategy. The twelve most use of viral marketing is ensures bank service quality. Viral marketing techniques that helps to ensure bank service quality that attract customer, is effective marketing strategy. The thirteen most use of viral marketing techniques is to increase repurchase intention. The website marketing provide right information that insist customer to get service and also to make repurchase. The fourteen most use of Facebook marketing are easily attract to customer and Facebook marketing is very cheaper than other marketing techniques. The fifteen most use of viral marketing techniques is to inform about unique service quality. Unique service quality is desirable to all customers. It attract customer most and effectively. According to the finding, to inform customer about unique service quality is the best use of marketing strategy. According to the analysis, my findings also suggest spreading information create brand image, ensuring service quality, and trustworthiness about a commercial bank good and service. If banks use those as a form of marketing strategy, it will bring effective results. Suppose the bank can create customer brand awareness, create a positive attitude in customer minds, and ensure high-level service quality, available information, and trustworthiness. In that case, it will be useful and effective use of viral marketing techniques.

\section{CONCLUSION}

Viral marketing has an influencing capacity of customer selection and the uses of service. These form of communication present a high degree experience and credence quality. The respondent wants to know information about the bank through Facebook, webpage and website. To attract potential customer, creating new customer, to reach target customers, building trustworthiness, establishing brand image, increase repurchase intention, informing unique service quality all of these are the different from of using viral marketing techniques, that is effective and useful to reach customer to hold existing customers and to convert existing customer into loyal customers. The recommendation for bank should be seen as advice that they should connect their customers with their best service. The main recommended issues of this study for bank are present below:

- Bank should use viral marketing strategy more to reach their potential customer. So, to catch up target customer, bank should use viral marketing techniques as marketing strategy because it takes a short time to go customers.

- For spreading bank information Facebook marketing techniques plays vital role. So bank should use this strategy to make information available. Bank can uphold strong their customer satisfaction level by using viral marketing techniques.

- Website is the best way to create trustworthiness and attract more existing customer. So banks should use viral marketing techniques to hold the existing ones that would be helpful 
for banks. Using viral marketing techniques is supportive to provide better service to bank clients. For this, bank can provide their best service by using viral marketing techniques as their marketing strategy.

- Using viral marketing techniques as marketing strategy is the best way to suggest service. Bank should use this strategy for collecting suggestion from customer that would be effective for them. To make clients happy viral marketing techniques should be used as marketing strategy to make them customer happy.

- To establish a new brand, bank should use viral marketing techniques effectively to reach the brand to their target customers. For this, bank can use viral marketing techniques as marketing strategy to reach their customers as a new brand. By using this strategy brand information would be available within a short time that is necessary and effective for bank.

\section{AUTHOR CONTRIBUTIONS}

Conceptualization: Dipu Roy, Sharmin Nahar Eti, Sabeha Jannat

Data Curation: Dipu Roy

Formal Analysis: Dipu Roy, Sharmin Nahar Eti, Sabeha Jannat

Funding Acquisition: Dipu Roy, Sharmin Nahar Eti, Sabeha Jannat

Investigation: Dipu Roy, Sharmin Nahar Eti, Sabeha Jannat

Methodology: Dipu Roy, Sharmin Nahar Eti, Sabeha Jannat

Project Administration: Dipu Roy

Resources: Dipu Roy

Software: Dipu Roy

Supervision: Dipu Roy

Validation: Dipu Roy, Sharmin Nahar Eti, Sabeha Jannat

Visualization: Dipu Roy, Sharmin Nahar Eti, Sabeha Jannat

Writing - Original Draft: Dipu Roy

Writing - Review \& Editing: Dipu Roy, Sharmin Nahar Eti, Sabeha Jannat

\section{CONFLICT OF INTEREST STATEMENT}

The authors declare that they have no competing interests.

\section{ACKNOWLEDGEMENT}

All authors contributed equally to the conception and design of the study.

\section{REFERENCES}

Abdullah, F., Ward, R., \& Ahmed, E. (2016). Investigating the influence of the most commonly used external variables of TAM on students' Perceived Ease of Use (PEOU) and Perceived Usefulness (PU) of e-portfolios. Computers in human behavior, 63, 75-90.

Al Amin, M., Arefin, M. S., Sultana, N., Islam, M. R., Jahan, I., \& Akhter, A. (2020). Evaluating the customers' dining attitudes, e-satisfaction and continuance intention toward mobile food ordering apps (MFOAs): evidence from Bangladesh. European Journal of Management and Business Economics, 30(2), 211-229. https://doi.org/10.1108/EJMBE04-2020-0066 
Akhter, A., Hossain, M. U., \& Asheq, A. A. (2020a). Influential factors of social entrepreneurial intention in Bangladesh. The Journal of Asian Finance, Economics, and Business, 7(8), 645-651.

Akhter, A., Asheq, A. A., Hossain, M. U., \& Karim, M. K. (2020b). Exploring customer intentions to adopt mobile banking services: Evidence from a developing country. Banks and Bank Systems, 15(2), 105-116.

Akhter, A., Karim, M. M. \& Islam, K. M. A. (2021). The impact of emotional intelligence, employee empowerment and cultural intelligence on commercial bank employees' job satisfaction. Banks and Bank Systems, 16(4), 11-21.

Asheq, A. A., Tanchi, K., Kamruzzaman, M., \& Karim, M. M. (2021). The impact of e-marketing orientation, technological orientation and learning capacity on online SME performance. Innovative Marketing, 17(3), 168-179.

Ali, M. C., Islam, K. M. A., Chung, S. J., Zayed, N. M., \& Islam, M. R. (2021). THE CORRELATION BETWEEN JOB-HOPPING ATTITUDE AND TURNOVER BEHAVIOR: A JOB SATISFACTION PERSPECTIVE IN BANGLADESH. International Journal of Business and Management Future, 5(1), 14-26.

Ali, M. C., Islam, K. M. A., Chung, S. J., Zayed, N. M., \& Afrin, M. (2020). A Study of Green Human Resources Management (GHRM) and Green Creativity for Human Resources Professionals. International Journal of Business and Management Future, 4(2), 57-67.

Baqir, M., Hussain, S., Waseem, R., \& Islam, K. M. A., (2020). Impact of Reward and Recognition, Supervisor Support on Employee Engagement. American International Journal of Business and Management Studies, 2(3), 8-21.

Batool, N., Hussain, S., Baqir, M., Islam, K. M. A., \& Hanif, M. (2021). Role of HR Technology And Training For The Development Of Employees. International Journal of Business and Management Future, 5(1), 1-13.

Bhattacharya, S., Gaurav, K., \& Ghosh, S. (2019). Viral marketing on social networks: An epidemiological perspective. Physica A: Statistical Mechanics and its Applications, 525, 478-490.

Lindgreen, A., Dobele, A., \& Vanhamme, J. (2013). Word-of-mouth and viral marketing referrals: what do we know? and what should we know. European Journal of Marketing, 47(7), 1028-1033.

Islam, K. M. A., \& Bhuiyan, A. B. (2021). Determinants of the effectiveness of internal Shariah audit: Evidence from Islamic banks in Bangladesh. The Journal of Asian Finance, Economics, and Business, 8(2), 223-230. 
Islam, K. M. A., \& Barghouthi, O. A. (2017). Risk Management of Islamic Banking: An Islamic Perspective. International Journal of Islamic Banking and Finance Research, 1(1), 25-28.

Islam, K. M. A., \& Miajee, M. R. K. (2018). Small and Medium Enterprises (SMEs) Financing in Bangladesh: A Review of Literature. International Journal of Small and Medium Enterprises, 1(1), 11-15.

Islam, K. M. A. (2016a). Financial Performance Comparison of Top Rated Banking Financial Institutions (BFIs) of Bangladesh. Indian Journal of Science, 23(85), 669-697.

Islam, K. M. A. (2016b). Factors influencing consumers purchase decision: a case study of Pantene shampoo. Indian Journal of Science, 23(88), 910-923.

Islam, K. M. A. (2016c). Corporate Governance: Conjecture and Modernism. Indian Journal of Science, 23(86), 798-817.

Islam, K. M. A., Alam, I., \& Al-Amin, D. M. (2015). Foreign exchange operation of private commercial banks in Bangladesh: A case study on AB Bank Limited. International Journal of Innovative Research and Creative Technology, 1(3). 296-304.

Hossain, S. A., Islam, M. N., Mahmud, M. S., \& Islam, K. M. A. (2017). Evaluation of Financial Performance of Commercial Banks in Bangladesh: Comparative Study Based on CAMEL Approach. The Millennium University Journal, 2(1), 54-77.

Islam, K. M. A. (2015). Throughput accounting: a case study. International Journal of Finance and Banking Research, 1(2), 19-23.

Islam, K. M. A., \& Barghouthi, O. A. (2017). Risk Management of Islamic Banking: An Islamic Perspective. International Journal of Islamic Banking and Finance Research, 1(1), 25-28.

Islam, K. M. A., Sadekin, M. S., Rahman, M., Chowdhury, M., \& Haque, A. (2021). The impact of Shariah supervisory board and Shariah audit committee on CSR adoption at Islamic banks. Journal of Asian Finance, Economics and Business (JAFEB), 8(3), 479-485.

Jahan, N., Ali, M. J., \& Al Asheq, A. (2020). Examining the key determinants of customer satisfaction Internet banking services in Bangladesh. Academy of Strategic Management Journal, 19(1), 1-6.

Karim, M. M., Bhuiyan, M. Y. A., Nath, S. K. D., \& Latif, W. B. (2021). Conceptual Framework of Recruitment and Selection Process. International Journal of Business and Social Research, 11(2), 18-25.

Karimi, S., \& Naghibi, H. S. (2015). Social media marketing (SMM) strategies for small to medium enterprises (SMEs). International Journal of Information, Business and Management, 7(4), 86-98. 
Kumar, B., Asheq, A. A., Rahaman, M., \& Karim, M. M. (2019). Determinants of Social Media Marketing Adoption among SMEs: A Conceptual Framework. Academy of Marketing Studies Journal, 23(3), 1-6.

Miller, R., \& Lammas, N. (2010). Social media and its implications for viral marketing. Asia Pacific Public Relations Journal, 11(1), 1-9.

Roy, S. K., Butaney, G., Sekhon, H., \& Butaney, B. (2014). Word-of-mouth and viral marketing activity of the on-line consumer: the role of loyalty chain stages theory. Journal of Strategic Marketing, 22(6), 494-512.

Sharif, A. M., \& Karim, M. (2017). Influence of job analysis program on employees: a study on selected companies of Bangladesh. International Journal of Scientific and Engineering Research, 8(5), 1221-1225.

Tu, B., Bhowmik, R., Hasan, M., Asheq, A. A., Rahaman, M., \& Chen, X. (2021). Graduate Students' Behavioral Intention of toward Social Entrepreneurship: Role of Social Vision, Innovativeness, Social Proactiveness, and Risk Taking. Sustainability, 13(11), 6386.

Tsekouropoulos, G. (2019). Viral advertising: message quality, trust and consumers intention to share the content in social media. International Journal of Technology Marketing, 13(2), 111-124.

Yang, H. (2013). Market mavens in social media: Examining young Chinese consumers' viral marketing attitude, eWOM motive, and behavior. Journal of Asia-Pacific Business, 14(2), 154-178.

\section{Copyrights}

Copyright for this article is retained by the author(s), with first publication rights granted to the journal. This is an open-access article distributed under the terms and conditions of the Creative Commons Attribution license (https://creativecommons.org/licenses/by/4.0). 